\title{
Bank Credit And Agricultural Output In South Africa: A Cobb-Douglas Empirical Analysis
}

Joseph Chisasa, University of South Africa, South Africa

Daniel Makina, Ph.D., University of South Africa, South Africa

\begin{abstract}
We empirically examine the impact of bank credit on agricultural output in South Africa using the Cobb-Douglas production function. We utilize time series data of agricultural output, bank credit, capital accumulation, labour and rainfall from 1970 - 2009. With agricultural output as the dependent variable, we determine OLS estimates of the Cobb-Douglas production function. We observe that bank credit has a positive and significant impact on agricultural output in South Africa. With other factors of production kept constant, a $1 \%$ increase in credit results in $0.6 \%$ increase in agricultural output. Capital accumulation is also observed to have a positive and significant impact on agricultural output, albeit lower than that of credit, as a $1 \%$ increase in capital accumulation results in $0.4 \%$ increase in output, other factors kept constant. In terms the Cobb-Douglas elasticities, the combined effect of credit (0.6\%) and capital accumulation (0.4\%) gives constant returns to scale, meaning that doubling the two inputs will double agricultural output.
\end{abstract}

Keywords: Agricultural Output; South Africa; Cobb-Douglas Function; Bank Credit

\section{INTRODUCTION}

C $\mathrm{n}$ the literature factors mentioned as contributing to agricultural growth include increased use of agricultural inputs (seed, fertilizers, pesticides, etc), technological change (result of research and development efforts) and technical efficiency (affected by the flow of information, better infrastructure, availability of funds and farmers' managerial expertise) (Igbal, Ahmad and Abbas, 2003: 469; Kohansal, Ghorbani and Mansoori, 2008; Nwosu et al., 2010:87-89). The higher use of all these factors requires the use of funds either from farmers' own equity or borrowings. Given that the low levels of savings in developing countries including South Africa which had an average savings ratios of 20\% between 1970 and 2009 (ratio computed from South African Reserve Bank time series statistics), credit is viewed as a significant input in agricultural production.

In order to understand whether credit has an implication on agricultural output, we must first explore the reasons for credit demand. Using the probit model, Oni, Amao and Ogbowa (2005) showed that education, distance to the financial institution, income of the farmer and use of fertilizer influence demand for credit among farming households. Zuberi (1989) who estimated the production function for Pakistan found that the impact of credit to come through financing of seed and fertilizer while observing the role of financing fixed investment to be insignificant. On the contrary, Qureshi and Shah (1992) found credit to impact agricultural output through the financing of capital investment. Specifically, they observed the responsiveness of agricultural output to capital investment to be larger than that to fertilizer.

A study in India by Sriram (2007: 245) argues that “... the causality of agricultural output with increased doses of credit cannot be clearly established ..." This view seems to suggest that the availability of credit to farmers will not necessarily result in increased output. However, Afangideh (1996: 74), using the simulation approach and data from 1970 - 2005 for Nigeria, found out that bank lending has a positive and significant effect on real gross 
national saving and real agricultural output. Supporting this view, Guirkinger and Boucher (2008:295) observed that credit constraints lower the value of agricultural output. Similarly, Olaitan (2006: 9) argues that lack of access to economic resources, especially finance, by both farmers and small to medium enterprises (SMEs) across Nigeria, continues to retard economic growth.

The rate at which the world population is expanding and lessons learnt from the 2008 global financial crisis make it important for research to be conducted on how farmers can access more bank credit in order to boost productivity. Poor people spend $50 \%$ to $70 \%$ of their income on food and have little capacity to adapt as prices rise and wages for unskilled labour fail to adjust accordingly (von Braun, 2008: 5). More than 2000 farmers in Northern Nigeria, with the financial support from the United States Agency for International Development (USAID), Gatsby Foundation and the Department for International Development (DFID), a United Kingdom government department, recorded over 300\% increase in productivity, enhanced income generation and improved livelihoods on the farm families (Singh and Ajeigbe, 2007:158). Although USAID, Gatsby Foundation and DFID are not credit granting institutions, these results suggest that smallholder farmers need external financial injections for them to increase output.

Contributions on the role of bank credit on agricultural output in the context of South African smallholder farmers have been done by Moyo (2002), Wynne and Lyne (2003) and Lahiff and Cousins (2005). An earlier study by Kalinda, Shute and Filson (1998: 598) shows that agricultural credit is recognized as one of the means by which small-scale farmers can increase their capital base. They argue that government's dominance as a major credit source is largely a reflection of the reluctance of private financial institutions to invest in rural markets and agricultural production.

A study in India by Tripathi and Prasad (2010: 81) indicates that land significantly affected the agricultural output growth during the 1950/51 - 1964/65 seasons and after that land became less significant. Currently, labour and capital are significantly affecting the agricultural output growth in India. Similarly, Lippman (2010: 92), commenting on Saudi Arabia's food security efforts, remarked that Saudis intend to use their capital to develop farm projects in countries with agricultural potential but who do not have adequate capital to purchase the irrigation pumps, tractors and harvesters, fertilizer, farm-to-market roads and refrigerated warehouses needed for major increases in output. Using Two-Limit Tobit analysis, Brehanu and Fufa (2008: 2221) observed that an increase in access to credit by small-scale farmers is one of the ways of enhancing agricultural productivity and reducing poverty in Ethiopia. The availability of credit is not in itself a guarantee for increased productivity if the macroeconomic environment is not stable (Eyo, 2008: 781; Cole, 2009: 219). Policy makers should therefore be careful not to overlook other macroeconomic pre-conditions necessary for credit to make a meaningful contribution to output.

The variables that enter the agricultural production function have received substantial attention in the literature (Lawal and Abdullahi, 2011; Sial et al. 2011; Das et al. 2009; Iqbal et al. 2003). The Cobb-Douglas production function has been applied in several studies to establish the correlation between credit and agricultural output (Ahmad, 2011; Bernard, 2009 and Iqbal et al. 2003). The general observation from these studies is that credit has significant positive impact on agriculture output and that its effect is immediate.

It is against this background that this paper examines the impact of bank credit on agricultural output in South Africa. The rest of the paper is structured as follows. Section 2 reviews trends of credit to the agricultural sector in South Africa. Section 3 describes the data and methodology employed to empirically examine the impact of credit. Section 4 presents empirical analyses and discussion of their implications. Finally, section 5 concludes.

\section{TRENDS OF BANK CREDIT TO THE AGRICULTURAL SECTOR IN SOUTH AFRICA}

The rural and agricultural sector is serviced by both informal and formal rural financial markets. The informal rural markets comprise self-help groups, stokvels (rotating savings and credit associations), burial societies and women associations. They offer finance to their members, the use of which can be for consumption, emergency, enterprise or farming (Machethe et al. 2011). The formal rural financial markets comprise commercial banks, NGOs, microfinance institutions, the Land and Agricultural Bank of South Africa (often referred to as the Land Bank) and 
agricultural co-operatives. The sources of agricultural credit in South Africa over the years reported in Du Randt and Makina (2012) are as shown in Figure 1 below.

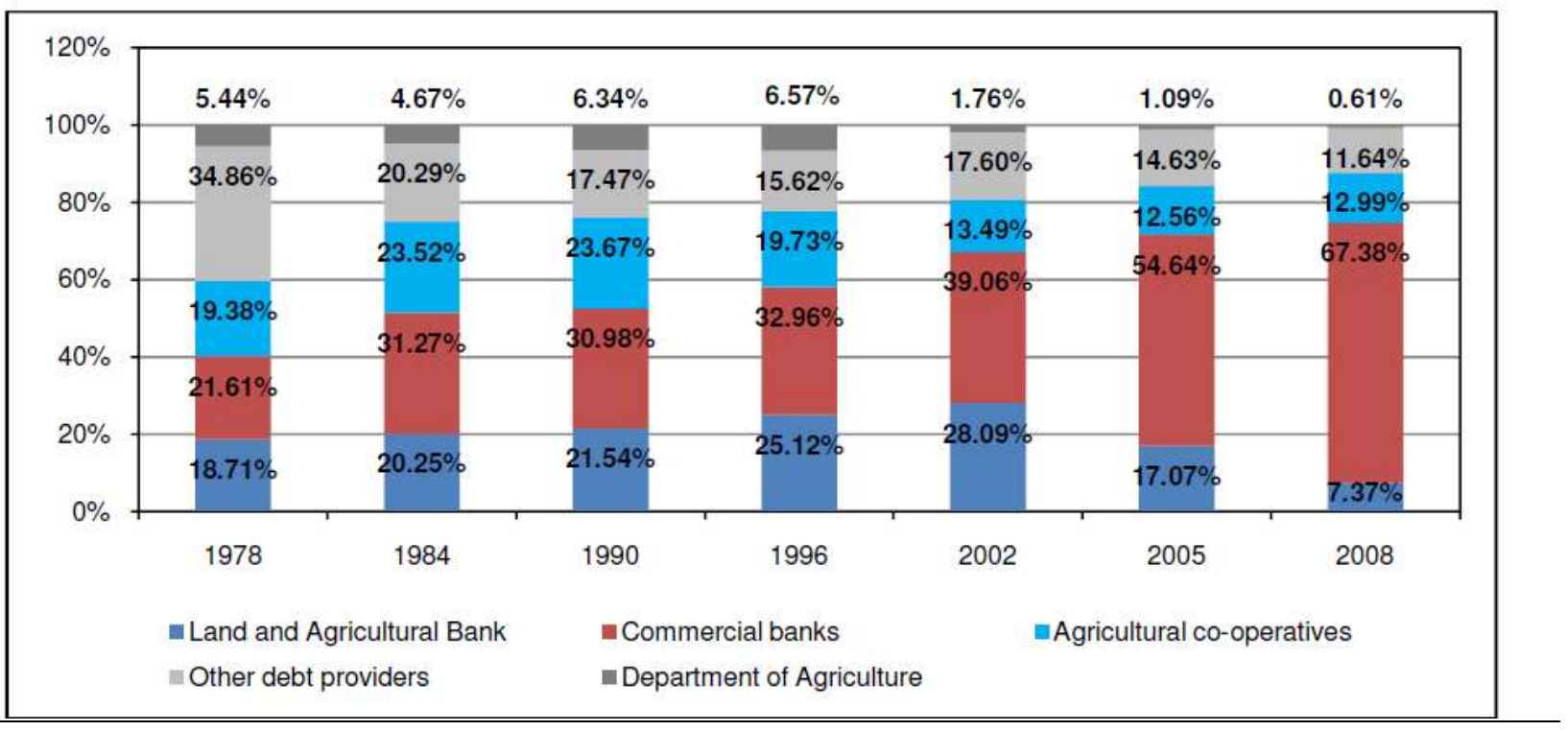

Figure 1: Agricultural Debt Distribution by Financial Institutions

Source: Calculations based on data from the Department of Agriculture, Forestry and Fisheries, 2009

Du Randt and Makina (2012) observed that the role of commercial banks in agricultural financing has seen an upward trend since 1980 (see Figure 1). Having been providing just over $20 \%$ of the total credit to the sector in 1978, commercial banks were providing over $67 \%$ of the total agricultural credit by the year 2008 . On the other hand, the role of the Land and Agricultural Bank was increasing during the same period until 2002 when it reached a peak, providing $28 \%$ of total credit to the agricultural sector. After 2002 there was a sharp decline in the role of the Land and Agricultural Bank in the sector and by the year 2008 it provided just over $7 \%$ of the total credit to the sector. The role of agricultural co-operatives was on an upward trend up to 1990, having risen from just over 19\% in 1978 to a peak of over $23 \%$ in 1990 . However, after 1990 their role declined by half and has stabilized at the same level. The declining role of agricultural co-operatives in providing credit was due the dismantling of their control of marketing boards that regulated prices in the agricultural sector ${ }^{1}$. Other debt providers of agricultural credit shown in Figure 1 who include informal sources had been declining over the years. The source of finance from the Department of Agriculture has been minimal over the years and has become insignificant (less than 1\%) by 2008 .

When we consider credit extended to the agricultural sector as a proportion of agricultural GDP (AGDP) we observe a declining trend over the years. Figure 2 is illustrative. Having been well over $100 \%$ of AGDP since the 1970s, it has dropped to below $100 \%$ in the recent years.

\footnotetext{
${ }^{1}$ The agricultural co-operatives used to have effective control of the Marketing Boards that regulated prices until this system was dismantled post-1994. As a result, many of the co-operatives in the late 1990s initiated processes to convert to limited liability companies.
} 


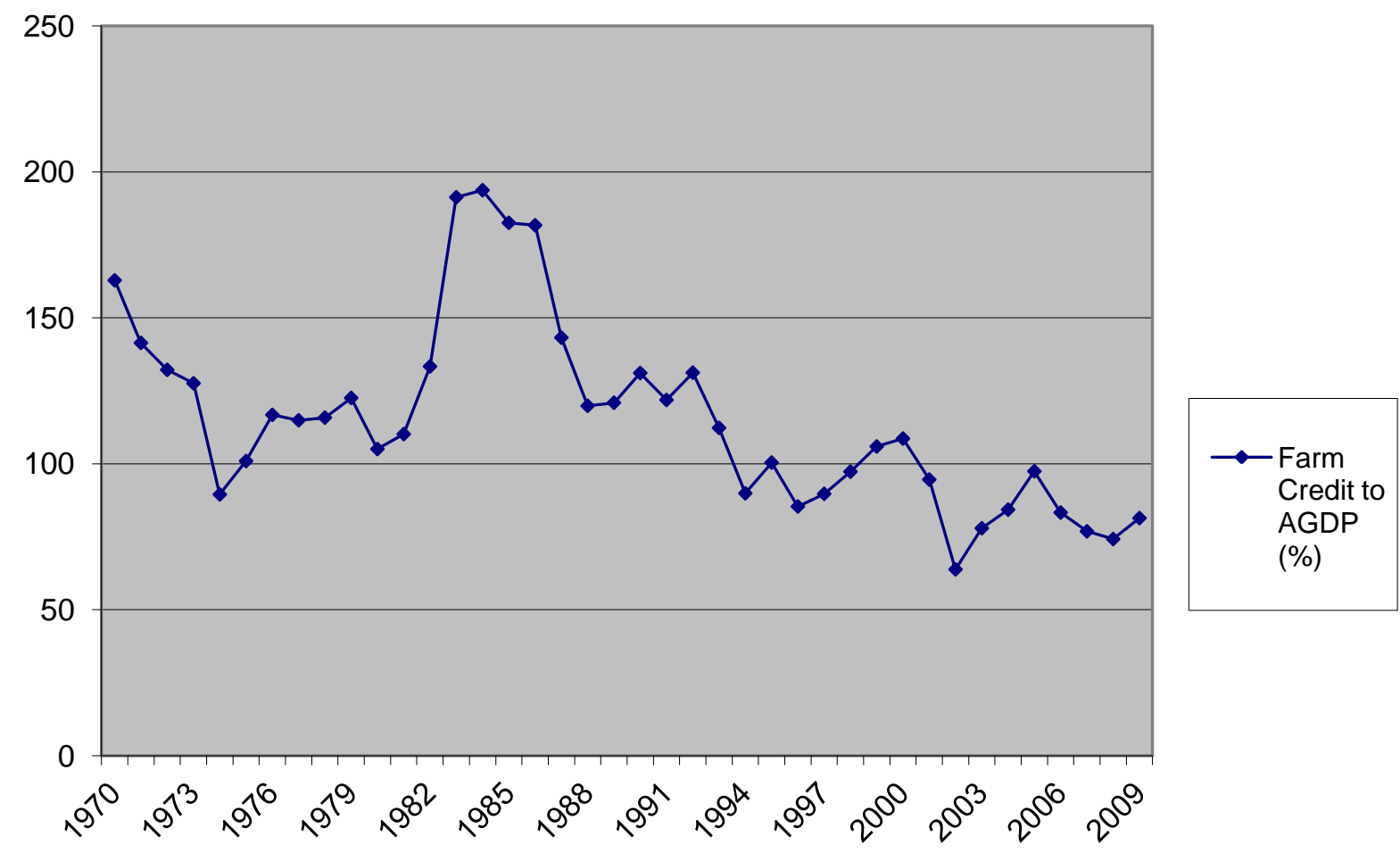

Figure 2: Ratio of total farm credit to AGDP

Source: South Africa. Department of Agriculture, Forestry and Fisheries, (2009)

Available literature on South Africa suggests that farmers are credit constrained resulting in poor performance (see for example Moyo, 2002; Kirsten and Van Zyl, 2003; Chisasa and Makina, 2012). Small farmers usually face challenges such as cumbersome procedures when applying for credit and collateral problems (Ahmad, 2011:101). Despite the development and adoption of models for managing default risk in credit portfolios (Bandyopandhyay, 2007), lending to agriculture has generally been lower than other real sectors in South Africa (see for instance, Wynne and Lyne, 2003). By the year 2010, banks' largest concentration of credit exposure was still to the private household sector while that to the agricultural sector was among those at the bottom (South African Reserve Bank, 2010).

\section{DATA AND METHODOLOGY}

\subsection{Data}

Secondary data was obtained from the Department of Agriculture, Fisheries and Forestry (DAFF) of South Africa and the South African Weather Service (SAWS). The total credit data used in the model consists of that supplied by the Land and Agricultural Bank of South Africa, commercial banks, agricultural cooperatives, Department of Agriculture, private persons, other financial institutions and other informal sources (DAFF, 2011:83). Details of the sources of credit are presented as Appendix A.

Consistent with the approach adopted by Iqbal et al. (2003) and Sial et al. (2011), we utilize time series data from 1970 - 2009 to estimate a Cobb-Douglas function in which agricultural gross domestic product (AGDP) is the dependent variable and credit, agricultural capital formation, agricultural labour force and rainfall are explanatory or independent variables. While the use of credit as an independent variable in the function has been challenged (see for example Driscoll (2004:469) and Nkurunziza (2010:489), Sial et al (2011:128) have posited that improved seeds and other inputs like tractors, fertilizer and biocides that may be purchased using credit money play 
an important role in agricultural production and these can be directly influenced by the availability of credit. Carter (1989) has given three reasons why credit should be an explanatory variable. First, credit availability alleviates liquidity constraints relating to purchase of inputs. Second, technical efficiency of farmers improves if credit is used to purchase new technology and enables a shift to the production frontier. Third, the availability of credit increases intensity use of fixed inputs (land, labour and management) to enhance resource allocation and profitability. Thus we would expect credit to have a positive impact on agricultural output.

The labour explanatory variable is based on data from the DAFF (2011: 4). Here it is the number of farm employees and domestic servants on farms. Ideally, agricultural labour hours would be the appropriate labour variable but these were not available. The coefficient of labour in the production function could either be positive (if labour is productive) or negative (if labour is not productive).

Agricultural capital accumulation (capital formation) that comprises fixed improvements, purchase of tractors and changes in the inventory of livestock is included as one of the explanatory variables. The expectation is that increases in agricultural physical assets should have a positive effect on output.

According to Rouault and Richard (2003:489) and Blignaut et al (2009:61), the eight most severe droughts in the history of South Africa since 1921 occurred in 1926, 1933, 1945, 1949, 1952, 1970, 1983 and 1982. Most of these episodes of severe drought were outside the time period 1970-2009 which is the focus of this study and hence it was considered imprudent to introduce a dummy variable for good years and bad years in the production function. In essence, save for three years, the period 1970-2009 were good years with regard to rainfall and visual inspection of the agricultural GDP (AGDP) data series does not show structural breaks in the three bad years of 1970, 1982-83. The coefficient of rainfall can either be positive (if rainfall positively affects output) or negative (if too much rainfall adversely affects output).

\subsection{Model Specification}

Cobb and Douglas (1928:151) hypothesized production as a function of labour $(L)$ and capital $(K)$. The Cobb-Douglas production function (as it later became known), is still the most ubiquitous tool in theoretical and empirical analysis of growth and productivity. It is widely used to represent the relationship of an output to inputs. Essentially, it considers a simplified view of the economy in which production output $(P)$ is determined by the amount of labour $(L)$ involved and the amount of capital $(\mathrm{K})$ invested, resulting in the following equation:

$P(L, K)=b L^{\alpha} K^{\beta}$

where $\alpha$ and $\beta$ are the output elasticities of labour and capital respectively. These values are constants determined by available technology. This model has been subjected to critical analyses since its inception (see for example, Samuelson, 1979 and Felipe and Adams, 2005). According to Tan (2008:5), there are concerns over its application in different industries and time periods. Tan argues that Cobb and Douglas were influenced by statistical evidence that appeared to show that labour and capital shares of total output were constant over time in developed countries. However, there is doubt over whether constancy over time exists. This argument is premised on the fact that the nature of the machinery and other capital goods (the $K$ ) differs between time periods and according to what is being produced. The same applies to the skills of labour $(L)$.

Notwithstanding its weaknesses, the Cobb-Douglas model has attractive mathematical characteristics, such as highlighting diminishing marginal returns to either factor of production. It is in this regard that we utilize it in this paper to estimate agricultural output as a function of credit, capital accumulation, labour and rainfall, an approach applied by Iqbal et al., (2003), Ahmad (2011) for Pakistan and Bernard (2009) and Enoma (2010) for Nigeria. Having regard that the production function is non-linear, we log-transform the Cobb-Douglas model to derive the following equation:

LnAGDP $=\beta_{0}($ constant $)+\beta_{1} \ln$ Credit $+\beta_{2} \ln$ Labour $+\beta_{3} \ln$ Capital accumulation $+\beta 4 \ln$ Rainfall $+\varepsilon_{t}$ 
where:

$\ln \mathrm{AGDP}=\quad \log$ of Agricultural gross domestic product measured in million Rands;

$\operatorname{lnCredit}=\quad \log$ of Bank credit disbursed from all institutions in million Rands;

$\ln$ Labour $=\quad \log$ of Labour force in millions;

lnCapital accumulation $=\log$ of annual changes in farm fixed improvements, machinery and inventory of livestock in million Rands;

$\operatorname{lnRainfall}=\quad \log$ of Annual rainfall in millilitres;

$B_{1}-\beta_{4}=\quad$ coefficients explaining the partial elasticities of explanatory variables. These values are constants $\varepsilon_{\mathrm{t}}=\quad \begin{array}{ll}\text { determined by } & \text { white noise. }\end{array}$

It is noteworthy that in this study the variable land was dropped and replaced with capital formation which includes fixed improvements on the land, tractors, machinery and implements. It is argued that the variable gross capital formation consists of the real factors which are applied directly in the production process rather than land per cultivated hectare used by Iqbal et al. (2003) and Sial et al. (2011).

\section{EMPIRICAL ANALYSIS AND DISCUSSION}

\subsection{Preliminary Analysis}

A trend analysis of AGDP, credit and capital formation was conducted and results are shown in Figure 3 below. Generally, the three variables have trended in the same direction over the years.

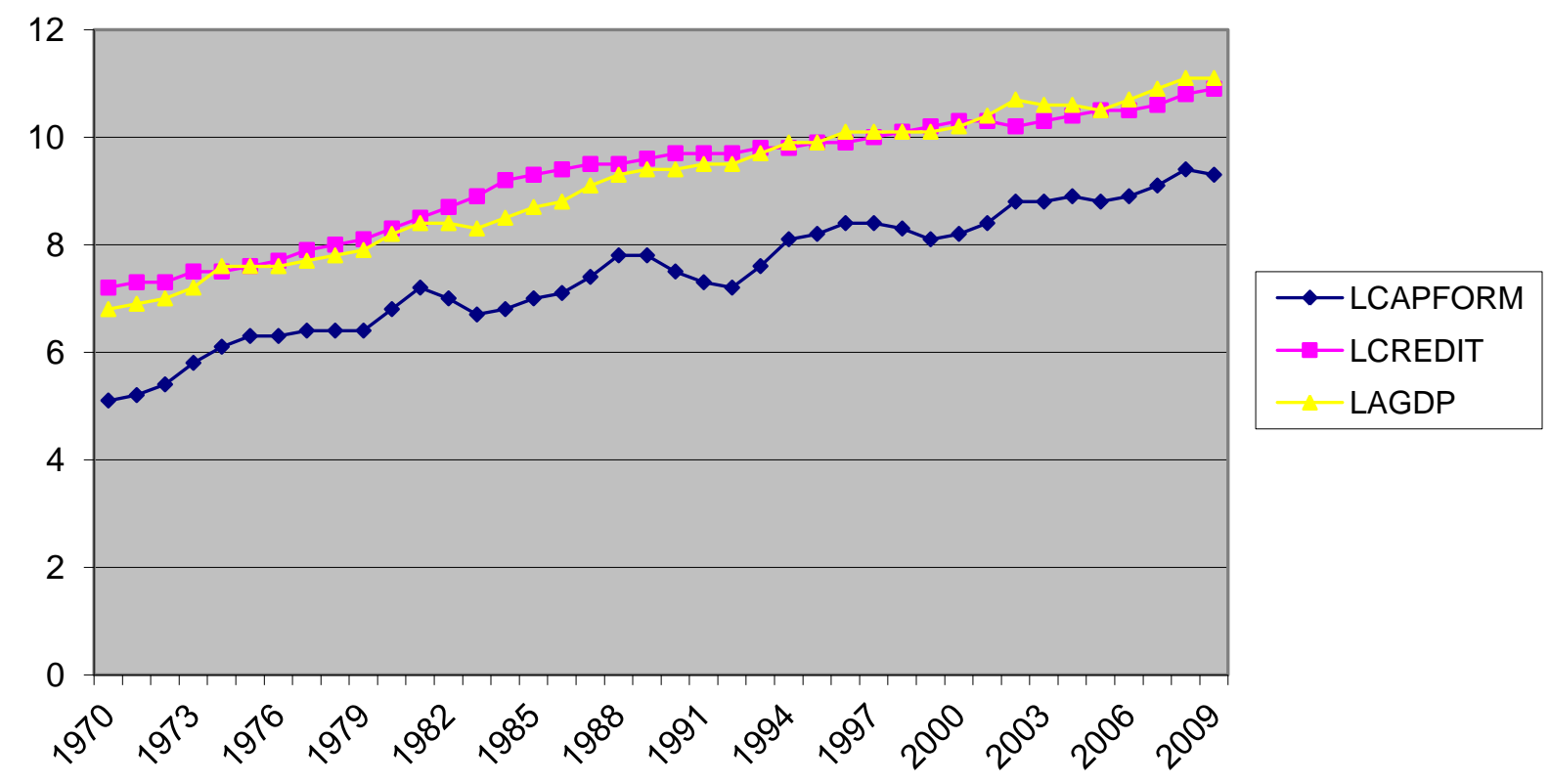

Figure 3: Trend of Variables over years Source: Author calculations

The graph shows quite an insightful trend between AGDP and the supply of credit extended to the agricultural sector over the years. From 1970 to 1980 the trend of AGDP and the supply credit was in tandem. However, from 1981 to 1993 the supply of credit trended higher than AGDP. It then trended lower from 1994 to 1999, briefly switching higher from 2001 and thereafter (since 2002) the trend of the supply of credit has been lower than that of AGDP. 
The data was subjected to unit root tests using the Augmented Dickey-Fuller and Phillips-Perron techniques. In levels, all variables were integrated of order one I (1). In differences, all the variables were observed to be integrated of order zero I ( 0 ) and hence the variables were transformed into difference form in subsequent analysis. Table 1 below summarises the unit root tests.

Table 1: Results of unit root tests

\begin{tabular}{|c|c|c|c|c|c|c|c|c|}
\hline \multirow[b]{2}{*}{ Variable } & \multirow[b]{2}{*}{$\begin{array}{c}\text { Level } \\
\text { with } \\
\text { Intercept }\end{array}$} & \multicolumn{2}{|c|}{ Augmented Dickey Fuller } & \multirow[b]{2}{*}{$\begin{array}{c}\text { Order of } \\
\text { Integration }\end{array}$} & \multirow[b]{2}{*}{$\begin{array}{l}\text { Level with } \\
\text { Intercept }\end{array}$} & \multicolumn{2}{|c|}{ Phillips \& Perron } & \multirow[b]{2}{*}{$\begin{array}{c}\text { Order of } \\
\text { Integration }\end{array}$} \\
\hline & & $\begin{array}{c}\text { Order of } \\
\text { Integration }\end{array}$ & $\begin{array}{c}\text { Ist } \\
\text { Difference } \\
\text { with } \\
\text { Intercept }\end{array}$ & & & $\begin{array}{l}\text { Order of } \\
\text { Integrati } \\
\quad \text { on }\end{array}$ & $\begin{array}{c}\text { Ist } \\
\text { Differenc } \\
\text { e with } \\
\text { Intercept }\end{array}$ & \\
\hline LAGDP & -1.4633 & $\mathrm{I}(1)$ & $-6.0954^{* * * *}$ & $\mathrm{I}(0)$ & $-4.7255^{* * *}$ & $\mathrm{I}(0)$ & $-6.6847^{* * * *}$ & $\mathrm{I}(0)$ \\
\hline LRAINFALL & -2.4395 & $\mathrm{I}(1)$ & $-8.8544^{* * * *}$ & $\mathrm{I}(0)$ & -2.4395 & $\mathrm{I}(1)$ & $-9.0840^{* * * *}$ & $\mathrm{I}(0)$ \\
\hline LCREDIT & -1.6401 & $\mathrm{I}(1)$ & $-3.1191^{* *}$ & $\mathrm{I}(0)$ & -1.4349 & $\mathrm{I}(1)$ & $-3.0228^{* * *}$ & $\mathrm{I}(0)$ \\
\hline LLABOUR & -2.1976 & $\mathrm{I}(1)$ & $-6.0699^{* * *}$ & $\mathrm{I}(0)$ & -2.1976 & $\mathrm{I}(1)$ & $-6.1396^{* * * *}$ & $\mathrm{I}(0)$ \\
\hline LCAPFORM & -1.2100 & $\mathrm{I}(1)$ & $-6.5073^{* * *}$ & $\mathrm{I}(0)$ & -2.1537 & $\mathrm{I}(1)$ & $-4.7498^{* * * *}$ & $\mathrm{I}(0)$ \\
\hline
\end{tabular}

Note: $* * *, * *$ and $*$ denote significance at 1,5 and $10 \%$ levels, respectively.

\section{MODEL ESTIMATION AND DISCUSSION}

After correcting the data for stationarity, a transformed equation [2] was estimated using EViews. The first output showed a low value of the Durbin-Watson statistic suggesting the presence of autocorrelation. In order to remove autocorrelation, the equation was re-estimated by adjusting for AR (1). The final estimates of the equation are shown in Table 2 below.

Table 2: The OLS Estimates of Cobb-Douglas Production Function

\begin{tabular}{|c|c|c|c|}
\hline Variables & Coefficient Estimates & t--Values & Significance \\
\hline Constant & 0.1835 & 0.6060 & 0.5486 \\
\hline DLCREDIT & 0.5932 & 6.0256 & $0.0000 * * *$ \\
\hline DLLABOUR & -0.0065 & -0.2847 & 0.7777 \\
\hline DLCAPITAL ACCUMULATION & 0.4153 & 5.7490 & $0.0000 * * *$ \\
\hline DLRAINFALL & -0.0431 & -0.6254 & 0.5360 \\
\hline $\operatorname{AR}(1)$ & 0.6570 & 4.1112 & $0.0002 * *$ \\
\hline
\end{tabular}

All the diagnostic tests were generally satisfactory in the estimated equation. The relationship between credit and output, gross capital formation and output were observed to be positive and significant at the $1 \%$ level of significance. Results show that a $1 \%$ increase in credit leads to a $0.6 \%$ rise in agricultural output, holding other factors constant. Similarly, a $1 \%$ increase in capital leads to a $0.4 \%$ rise in agricultural output, holding other factors constant. In terms of the Cobb-Douglas elasticities, the combined effect of credit $(0.6 \%)$ and capital accumulation $(0.4 \%)$ gives constant returns to scale, meaning that doubling the two inputs will double agricultural output. The partial elasticities of labour and rainfall were observed to be negative but insignificant.

Our results are consistent with those of Iqbal et al. (2003:477) and Sial et al. (2011:131) for Pakistan (see Table 3). What is evident from these results is that credit has a positive and significant relationship with agricultural output. 
Table 3: Comparative studies

\begin{tabular}{|l|c|c|c|}
\hline \multicolumn{1}{|c|}{ Statistic } & \multicolumn{2}{c|}{ Authors } \\
\hline DLCredit & This study (South Africa) & Sial et al. 2011 (Pakistan) & Iqbal et al. 2003 (Pakistan) \\
\hline DLLabour & $0.5932^{* * * *}$ & $0.167^{*}$ & $0.0801^{* * *}$ \\
\hline DLCapital formation & -0.0065 & $0.639^{* * *}$ & $0.7783^{* * *}$ \\
\hline Crop intensity & $0.4153^{* * * *}$ & Not used & Not used \\
\hline DLRainfall & Not used & $1.399^{*}$ & 0.5519 \\
\hline AR(1) & $-0.0431^{* * *}$ & $1.063^{* *}$ & $0.6259^{* * *}$ \\
\hline MA(1) & $0.0002^{* * *}$ & $0.255^{* *}$ & $0.5209^{* * *}$ \\
\hline R $^{2}$ & Not used & $0.979^{* *}$ & $0.6832^{* * * *}$ \\
\hline Adjusted R ${ }^{*}$ & 0.994 & 0.96 & 0.98 \\
\hline F-statistic & 0.993 & - & 0.98 \\
\hline DW & 953.9 & 160.1 & 162.165 \\
\hline
\end{tabular}

$*, * *, * * *$ denote significance at $10 \%, 5 \%$ and $1 \%$ levels respectively

\section{CONCLUSION}

The paper has empirically examined the impact of bank credit on agricultural output in South Africa using the Cobb-Douglas production function. It is observed that bank credit has a positive and significant impact on agricultural output. With other factors of production kept constant, a $1 \%$ increase in credit results in $0.6 \%$ increase in agricultural output. Similarly, capital accumulation is observed to have a positive and significant impact on agricultural output, albeit lower than that of credit, as a $1 \%$ increase in capital accumulation results in $0.4 \%$ increase in output, other factors kept constant. In terms the Cobb-Douglas elasticities, the combined effect of credit $(0.6 \%)$ and capital accumulation (0.4\%) gives constant returns to scale, meaning that doubling the two inputs will double agricultural output. The partial elasticities of labour and rainfall were observed to be negative but insignificant.

While the results are consistent with other empirical studies that used the same analytical approach, we intend to do further research on the relationship of bank credit and agricultural output using dynamic analytical techniques that address shortcomings of the Cobb-Douglas model.

\section{ACKNOWLEDGEMENT}

The paper is based on a doctoral research project of the first author entitled: An Empirical Study of the Impact of Bank Credit on Agricultural Output in South Africa. Correspondence should be addressed to Joseph Chisasa at UNISA, Private Box 392, Pretoria 0003, e-mail: Chisaj@unisa.ac.za, Telephone: +27 (12) 4294613.

\section{AUTHOR INFORMATION}

Mr. Joseph Chisasa is a Senior Lecturer in the Department of Finance, Risk Management and Banking of the University of South Africa. He holds a Master of Science Degree in Finance and Investment and a Bachelor of Commerce Degree in Banking (Honours). He is a Certified Associate of the Institute of Bankers of South Africa, Associate Member of the Institute of Bankers of Zimbabwe and an Associate Member of the Institute of Credit Management of South Africa. He has published in the International Business and Economics Research Journal. His research interests are in banking and credit risk management. E-mail: Chisaj@ unisa.ac.za (Corresponding author)

Dr. Daniel Makina is a Professor of Finance and Banking in the Department of Finance, Risk Management and Banking of the University of South Africa. He has published in recognized national and international journals that include: Applied Financial Economics, Applied Economics, International Business and Economics Research Journal, Journal of Developing Societies, Journal of Accounting and Finance Research, Business Review, African Development Review, African Finance Journal, among others. His research interests are in emerging financial markets, banking and migration issues related to financial development. Address: University of South Africa, PO Box 392, Pretoria 0003, South Africa. E-mail: makind@unisa.ac.za 


\section{REFERENCES}

1. Afangideh, U.J. 1996. Financial development and agricultural investment in Nigeria: historical simulation approach. Journal of Economic and Monetary Integration, 9(1) pp.74-97.

2. Ahmad, N. 2011. Impact of institutional credit on agricultural output: A case study of Pakistan. Theoretical and Applied Economics, 10 (563) pp. 99-120.

3. Bandyopadhyay, A. 2007. Credit risk models for managing bank's loan portfolio. [Online] Available from: http://mpra.ub.uni-muenchen.de/5358/ [Downloaded: 2012-07-12].

4. Bernard, O.A. 2009. An empirical analysis of credit supply and agricultural output in Nigeria. [Online] Available from: http://www.scribd.com/doc/23834331/Credit-SS-Agric-Output [Downloaded: 2012-0710].

5. Blignaut, J., Ueckermann, L. \& Aronson, J. 2009. Agriculture production's sensitivity to changes in climate change in South Africa. South African Journal of Science, 105 pp. 61-67.

6. Brehanu, A. \& Fufa, B., 2008. Repayment rate of loans from semi-formal financial institutions among small-scale farmers in Ethiopia: Two-limit Tobit analysis. The Journal of Socio Economics, 37, pp. 22212230.

7. Carter, M.R. 1989. The impact of credit on peasant productivity and differentiation in Nicaragua. Journal of Development Economics, 31. pp 13-36.

8. Chisasa, J. \& Makina, D. 2012. Trends in credit to smallholder farmers in South Africa. International Business and Economics Research Journal, 11(7) pp. 771-784.

9. Cobb, C.W. \& Douglas, P.H. 1928. A Theory of production. The American Economic Review, 18(1) pp. 139-165.

10. Cole, S. 2009. Fixing market failures or fixing Elections? Agricultural credit in India. American Economic Journal: Applied Economics, 1(1) pp. 219-50.

11. Das, A., Senapati, M. \& John, J. 2009. Impact of agricultural credit on agriculture production: an empirical analysis in India. Reserve Bank of India Occasional Papers, 30(2) pp. 75-107.

12. Driscoll, C.D. 2004. Does bank lending affect output? Evidence from the U.S. states. Journal of Monetary Economics, 51. pp.451-471.

13. Du Randt, R. and Makina, D. 2012. An Appraisal of Agricultural Financing Models in South Africa. Paper presented at the Southern African Finance Association Conference, January 18-20, 2012, Cape Town, South Africa.

14. Enoma, A. 2010. Agricultural credit and economic growth in Nigeria: An empirical analysis. Business and Economics Journal, 14. pp. 1-7.

15. Eyo, E.O. 2008. Macroeconomic environment and agricultural sector growth in Nigeria. World Journal of Agricultural Sciences, 4(6) pp. 781-786.

16. Felipe, J. \& Adams, F.G. 2005. "A theory of production." The estimation of the Cobb-Douglas function: A retrospective view. Eastern Economic Journal, 31(3) pp. 427-445.

17. Guirkinger, C. \& Boucher, S.R., 2008. Credit constraints and productivity in Peruvian agriculture. The Journal of the International Association of Agricultural Economics, 39. pp. 295-308.

18. Iqbal, M., Ahmad, M. \& Abbas, K. 2003. The impact of institutional credit on agricultural production in Pakistan. The Pakistan Development Review, 42(4) Part II. pp. 469-485.

19. Kalinda, T.H., Shute, J.C. \& Filson, G.C., 1998. Access to agricultural extension, credit and markets among small-scale farmers in southern Zambia. Development Southern Africa, 4. pp. 589-608.

20. Kirsten, J. \& Vink, N. 2003. Policy Module South Africa. Presented under the Roles of Agriculture Project in International Conference on 22 - 22 October 2003 Rome, Italy. Agricultural and Development Economics Division, Food and Agricultural Organisation of the United Nations. [Online] Available from: http://ftp.fao.org/es/esa/roa/pdf/1_Policy/Policy_SouthAfrica.pdf Downloaded: 2012-08-22].

21. Kohansal, M.R., Ghorbani \& Mansoori, H. 2008. Effect of credit accessibility of farmers on agricultural investment and investigation of policy options in Khorasan-Razavi Province. Journal of Applied Sciences, 8(23) pp. 4455-4459.

22. Lahiff, E. \& Cousins, B., 2005. Smallholder agriculture and land reform in South Africa. Institute of Development Studies Bulletin, 36(2) pp. 127-131. 
23. Lawal, W.A. \& Abdullahi, I.B. 2011. Impact of informal agricultural financing on agricultural production in the rural economy of Kwara State, Nigeria. International Journal of Business and Social Science, 2(19) pp. 241-248.

24. Lippman, T.W. 2010. Saudi Arabia's quest for “food security”. Middle East Policy, XVII(1) pp. 90-98.

25. Machethe, C, Moyo, T, Mahlati, V. and Coetzee, G. 2011. The State of Rural and Agricultural Finance in SADC: Some initial findings. Centre for Inclusive Banking in Africa, University of Pretoria.

26. Moyo, S. 2002. Using market research to inform product development: the case of small farmer financial products in South Africa. Agrekon, 41(2) pp. 189-194.

27. Nkurunziza, J.D. 2010. The effect of credit on growth and convergence of firm size in Kenyan manufacturing. The Journal of Trade and Economic Development, 19(3) pp. 465-494.

28. Nwosu, F.O., Oguoma, N.N.O., Ben-Chendo, N.G. \& Henri-Ukoha, A. 2010. The agricultural credit guarantee scheme: its roles, problems and prospects in Nigeria's quest for agricultural development. Researcher, 2(2) pp. 87-90.

29. Olaitan, M.A. 2006. Finance for small and medium enterprises: Nigeria's agricultural credit guarantee scheme fund. Journal of International Farm Management, 3(2) pp. 1-9.

30. Oni, O.A, Amao, J.O. \& Ogbowa, O. 2005. Determinants of credit demand among rural farming households in Ose Local Government Area: Ondo State of Nigeria. Journal of Financial Management and Analysis, 18(2) pp.76-80.

31. Qureshi, S.K. and Shah, A.H. 1992. The Pakistan Development Review 31(4) pp. 781-801.

32. Rouault, J. \& Richard, Y. 2003. Intensity and spatial extension of drought in South Africa at different time scales. Water SA, 29(4) pp. 489-500.

33. Samuelson, P.A. 1979. Paul Douglas's measurement of production functions and marginal productivities. Journal of Political Economy, 923-39.

34. Sial, M.H., Awan, M.S. \& Waqas, M. 2011. Role of institutional credit on agricultural production: A time series analysis of Pakistan. International Journal of Economics and Finance, 3(2) pp. 126-132.

35. Singh, B.B. \& Ajeigbe, H., 2007. Improved cowpea-cereals-based cropping systems for household food security and poverty reduction in West Africa. Journal of Crop Improvement, 19(1/2) pp. 157-172.

36. South Africa. 2009. Department of Agriculture, Forestry and Fisheries, Abstract of agricultural statistics, [Accessed 19 August 2011 (http://www.daff.gov.za).]

37. South Africa. 2011. Department of Agriculture, Forestry and Fisheries, Abstract of agricultural statistics, [Accessed 19 August 2011 (http://www.daff.gov.za).]

38. South African Reserve Bank (2010) Annual report. [Accessed 30 August 2011 (http://www.resbank.co.za/Lists/News\%20and\%20Publications/Attachments/4666/Annual\%20Report\%202 010-11.pdf).].

39. Sriram, M.S. 2007. Productivity of rural credit: a review of issues and some recent literature. International Journal of Rural Management, 3. pp. 245.

40. Tan, B.H. 2008. Cobb-Douglas production function. [Online] Available from: http://docents.fe.unl.pt/ jamador/Macro/cob-douglas.pdf [Downloaded: 2012-07-29].

41. Tripathi, A. \& Prasad, A.R., 2010. An overview of agrarian economy of India: performance and determinants. Journal of Agricultural Economics, VII (2) pp. 62-82.

42. Von Braun, J., 2008. Food and financial crises: Implications for agriculture and the poor. International Research Institute, Food Policy Report: 1-17. [Online] Available from: http://books.google.com [Downloaded: 2010-06-29].

43. Wynne, A.T., \& Lyne, M.C. 2003. An empirical analysis of factors affecting the growth of small-scale poultry enterprises in KwaZulu-Natal. Development Southern Africa, 20(5) pp. 563-577.

44. Zuberi, H.A. 1989. Production Function, Institutional Credit and Agricultural Development in Pakistan. The Pakistan Development Review 28(1) pp. 43-56. 
APPENDIX A: Credit data economic indicators

\begin{tabular}{|c|c|c|c|c|c|c|c|c|}
\hline Year & $\begin{array}{l}\text { CPI } \\
(\%)\end{array}$ & $\begin{array}{l}\text { Lend- } \\
\text { ing } \\
\text { rates } \\
(\%)\end{array}$ & $\begin{array}{c}\text { GDP } \\
\text { Nominal } \\
\text { Prices }\end{array}$ & $\begin{array}{l}\text { Small- } \\
\text { holder } \\
\text { debt } \\
(\mathbf{R m})\end{array}$ & $\begin{array}{l}\text { Commercial } \\
\text { farm debt } \\
(\mathbf{R m})\end{array}$ & $\begin{array}{c}\text { Total farm } \\
\text { debt } \\
\text { (Rm) }\end{array}$ & $\begin{array}{c}\text { Credit to } \\
\text { domestic private } \\
\text { sector }(\mathbf{R m})\end{array}$ & $\begin{array}{l}\text { Total credit } \\
\text { (Rm) }\end{array}$ \\
\hline 1986 & 19 & 14 & 123147 & 4907 & 7506 & 12412 & 27732 & 40144 \\
\hline 1987 & 16 & 13 & 125733 & 4428 & 7663 & 12880 & 34447 & 47327 \\
\hline 1988 & 13 & 15 & 131016 & 5665 & 7696 & 13361 & 44253 & 57614 \\
\hline 1989 & 15 & 20 & 134025 & 5951 & 8959 & 14910 & 51894 & 66804 \\
\hline 1990 & 14 & 21 & 133409 & 6678 & 9295 & 15973 & 59506 & 75479 \\
\hline 1991 & 15 & 19 & 132890 & 7515 & 9332 & 16847 & 70235 & 87082 \\
\hline 1992 & 14 & 19 & 130126 & 7425 & 9707 & 17132 & 82395 & 99527 \\
\hline 1993 & 10 & 16 & 1066215 & 8073 & 10214 & 18287 & 97014 & 115301 \\
\hline 1994 & 9 & 16 & 1100334 & 7808 & 10375 & 18184 & 114348 & 132532 \\
\hline 1995 & 9 & 18 & 1134445 & 7899 & 11497 & 19396 & 136267 & 155663 \\
\hline 1996 & 7 & 20 & 1183226 & 7956 & 12293 & 20250 & 159241 & 179491 \\
\hline 1997 & 9 & 20 & 1213990 & 8284 & 14267 & 22550 & 177442 & 199992 \\
\hline 1998 & 7 & 22 & 1220060 & 8341 & 16410 & 24751 & 195177 & 219928 \\
\hline 1999 & 5 & 18 & 1249341 & 8604 & 19125 & 27725 & 203185 & 230913 \\
\hline 2000 & 5 & 15 & 1301813 & 8445 & 21381 & 29826 & 226269 & 256095 \\
\hline 2001 & 6 & 14 & 1336962 & 7931 & 22895 & 30826 & 259162 & 289988 \\
\hline 2002 & 9 & 16 & 1386435 & 8462 & 19770 & 28232 & 286002 & 314234 \\
\hline 2003 & 6 & 15 & 1427322 & 8633 & 22259 & 30891 & 331842 & 362733 \\
\hline 2004 & -1 & 11 & 1492330 & 8882 & 24404 & 33286 & 412769 & 446055 \\
\hline 2005 & 2 & 11 & 1571082 & 9438 & 27006 & 36444 & 526647 & 563091 \\
\hline 2006 & 3 & 11 & 1659122 & 9832 & 27942 & 37774 & 684593 & 722367 \\
\hline 2007 & 6 & 13 & 1751499 & 10479 & 30900 & 41380 & 853819 & 895199 \\
\hline 2008 & 10 & 15 & 1814134 & 10982 & 36063 & 47044 & 966921 & 1013965 \\
\hline 2009 & 7 & 12 & 1783617 & 12076 & 39865 & 51942 & 1001946 & 1053888 \\
\hline
\end{tabular}

Source: Statssa, SARB and Department of Agriculture, Forestry and Fisheries 
NOTES 